\title{
1932 and all that: documenting Free State, Catholic Ireland on film
}

\author{
Harvey O’Brien*
}

Resumo: A relação entre a mídia e o catolicismo é de particular interesse na história irlandesa, pois existe uma tradição de cooperação tácita e explícita que dominou durante grande parte do século XX, para terminar em amarga aclamação na década de 1990. Examinando o legado da ligação entre os sacerdotes cineastas e o envolvimento de organizações religiosas na produção de filmes na Irlanda, vemos um padrão de concentração no princípio do testemunho no filme de não-ficção assim como na crença religiosa, o que coloca o documentário como um registo passivo de fé na Irlanda do século XX.

Palavras-chave: sacerdotes cineastas; documentário; Irlanda.

Resumen: La relación entre los medios y el catolicismo es de particular interés en la historia irlandesa, dada la tradición de cooperación tácita y explícita que dominó durante gran parte del siglo XX, solo para terminar en amarga aclamación en la década de 1990. Examinando el legado de la relación entre los sacerdotes cineastas y la participación de organizaciones religiosas en la producción cinematográfica en Irlanda, vemos un patrón de concentración en el principio del testimonio en las películas de no ficción, así como en las creencias religiosas, lo que hace del documental un registro pasivo de la fe en la Irlanda del siglo XX.

Palabras clave: sacerdotes directores; cine documental; Irlanda.

Abstract: The relationship between the media and Catholicism is of particular interest in Irish history given the tradition of tacit and explicit co-operation that held sway throughout much of the twentieth century, only to end in bitter acrimony in the 1990s. Examining the legacy of the links between filmmaking priests and the involvement of religious organisations in making films in Ireland, we see a pattern of concentration of the principles of bearing witness in non-fiction film and in religious belief that problematise the status of the documentary film as a passive recorder of faith in twentieth century Irland.

Keywords: filmmaking priests; documentary; Irland.

Résumé: La relation entre les médias et le catholicisme est d'un intérêt particulier dans l'histoire irlandaise, compte tenu de la tradition de coopération tacite et explicite qui a dominé une grande partie du XXe siècle, pour trouver dans une issue amère

* University College Dublin - UCD, School of English, Drama and Film, Film Studies. Belfield - Dublin4, Dublin, Republic of Ireland. E-mail: harvey.obrien@ucd.ie

This article is based on a paper first presented at the Catholicism and Public Cultures in Ireland, France, United Kingdom and North America Conference, Institute of Art Design Technology, Dun Laoghaire, June 17-19 2009.

Submission of the article: november 14th, 2016. Notification of acceptance: december 31st, 2016.

Doc On-line, n. 21, março de 2017, www.doc.ubi.pt, pp. 30-40. 
dans les années 1990. En examinant l'héritage du lien entre les religieux cinéastes et l'engagement des organisations religieuses dans la production cinématographique en Irlande, nous observons une tendance à se baser plutôt sur les témoignages dans le film de non-fiction et dans la croyance religieuse, ce qui réduit le documentaire à un simple moyen d'enregistrement passif de la foi en Irlande au XXe siècle. Mots-clés: cinéastes prêtres, documentaire, Irlande.

In the 2004 book on Irish documentary film, The Real Ireland (Manchester University Press, 2004), I wrote about Fr. Frank Browne's filmic record of the Eucharistic Congress of 1932 under the heading 'Triumph of the Catholic Will', which raised a few eyebrows. Was I really comparing the Catholic Church to the Nazis? No. I was talking about the ways in which the intersection of documentary filmmaking and public culture raises important questions about how we conceive of the very idea of a public culture. Central to the issue raised in the book is the concept of documentary film itself - of how we think of it and what uses we put it to, and, indeed, how we define the meaning of the word 'we' in the context of any given culture or society. In particular my focus both then and now was Catholic Public Culture in Free State Ireland: the context of how the Eucharistic Congress of 1932 was conceived of and represented. Although the Congress was a significant event in Free State Ireland, the infrastructure of film production was comparatively underdeveloped, and though there was an active network of amateur filmmakers, there was no concerted effort to 'cover' the event in the way in which we now consider standard procedure both in professional and amateur media. But what material there is points to the role documentary plays in the formation of public culture, something that was particularly important in the 1930s.

Briefly, it should be borne in mind that that was the period in world film culture when non-fiction filmmaking moved from the demense of what Bill Nichols terms the 'poetic mode' which "stresses mood, tone, and affect than displays of factual knowledge" (Nichols, 2010: 162) to the expository or rhetorical mode of filmmaking associated with John Grierson and the British Documentary Film Movement. When Grierson conceived of this type of film, which was at least partially an extension of print journalism, he actually wasn't particularly interested in film per se. It was what could be achieved in social and political terms through the use of film that was important. In his own words:

... the documentary idea was not basically a film idea at all, and the film treatment it inspired only an incidental aspect of it. The medium happened to be the most convenient and most exciting available to us. The idea itself, on the other hand, was a new idea for public education: its underlying concept that the world was in a phase of drastic change affecting every manner of thought and practice, and the public comprehension of the nature of that change vital. 
There it is, exploratory, experimental and stumbling, in the films themselves: from the dramatisation of the workman and his daily work to the dramatization of modern organisation and the new corporate elements in society to the dramatisation of social problems: each a step in the attempt to understand the stubborn raw material of our modern citizenship and wake the heart and the will to their mastery. (Grierson,1942 in Aitken, 1998: 106).

Grierson's achievement was first of all in establishing the principle of the role of film (still a new medium) in public education, and secondly in linking the production of such films to both state and corporate sponsorship, envisioned as a type of mutual social self-interest grounded in the common goal of social unity. Aitken (2013) examines this in terms of a Hegelian idealism in which, as he puts it, Grierson regarded himself as one of the "torch bearers" (2013: 129) of a movement towards a benevolent collaboration between state and private interests in the name of progress and progressiveness. The world was indeed in a phase of drastic change in the 1930s as public cultures began to take new shapes - the New Deal in America, European fascisms, the re-definition of Britain after the Empire, and, in Free State Ireland, the consolidation and formalisation of the relationship between the Church, the State, and the People a decade after Independence.

There is a very strong link between national identity, public culture, and the social documentary in as much as even today the expository or rhetorical (often called 'Griersonian') documentary produced and received on mainstream media is still considered to represent what Nichols refers to as "the voice of God" (2010: 61), or a voice of authority. Even in the age of alternative facts, there remains a degree of ethical trust placed in 'reputable' news sources stemming from the very roots of the Griersonian model. Essentially, this kind of documentary film even in practical terms began, to emerge when State sponsorship, support, or funding of one kind or another was given over to filmmakers who made films about the operations of that State or the lives of its people: as Grierson said, the idea behind it being both public education and an attempt to wake the heart and the will to the mastery of the raw material of modern citizenship - a citizenship defined by the State. The level of independence from Governmental authority demonstrated by documentary filmmakers varied from country to country and also over time, but the sense of direct interconnection between documentary practice and the social consensus was very strong in documentary film as it was conceived of at this time. The point here is that when attempting to understand the role of documentary film in public culture, it is important to be able to identify and quantify the presence of the voice of authority into which the documentary film becomes inculcated, either directly 
as in the case of State-sponsored film or indirectly in the case of defining the overall epistemological ethos within which any filmmaker operates.

In the case of Free State Ireland, the situation is extremely clear cut: here you have a new Nation, or at least a new State if you want to be more precise - a country consciously constructing an identity for itself rooted in its beliefs about its nationhood, history and heritage, but eager to distance itself from quite a substantial amount of that history, or at least to change what was 'official' history to reflect continuity with history before the occupation. As Kiberd (1995) and others have written about extensively, the Celtic revivalism of the late 19th and early twentieth centuries, in which tales from Irish mythology were freely intertwined with the new mythos of rebellion, was a conscious reaction to the sense of belonging and Empire that was fostered by official culture under the Crown. Religion played a central and vital part in stating and establishing Irish 'difference' from Britishness - the maintenance of continuity with Catholicism being an absolute lynchpin to the argument that Irish culture had survived all the time in an unbroken line, its loyalty always to Catholic Church, and never, therefore to the British Crown and Protestantism. Allegiance to the Catholic Church shown by Irish governments from Independence on was a significant factor in how legislation was worded and what it said.

In his 1998 book Moral Monoply, Tom Inglis goes into the exact operations of this in some detail. He describes how the Church exerted authority in Ireland, both in terms of its direct and its indirect influence (on policy on one hand and on behaviour on the other), and makes the point that: "With its monopoly over the definition of morality, the Church became a power bloc that was able to limit the practice and discourse not just of the state but other interest groups and alliances in Irish society," (Inglis, 1998: 93). Here we see a description of exactly the kind of psychic and social interconnection that I' $m$ talking about when I speak of the social documentary. The limits on practice and discourse that Inglis refers to here are equally placed on any type of representation, and not just through legislation and censorship, though we certainly had that, but also through a sense of society that meant that adherence to this mindset produced a social consensus based at least partly on this particular religious ethos. As Inglis says: "Irish Catholics rarely adhered to the Church for purely religious reasons. Being spiritual and moral and following the teaching and practices of the Church were not simply ends in themselves; they were also means of attaining and maintaining power. The implications of religious activity reached beyond the religious field into other social fields. Being Catholic was as much a public as it was a private affair," (Inglis, 1998: 68). Here we have again that word 'public' and the idea of public practice essentially gi- 
ving us a public culture - be it rooted in belief or truth or not. In this kind of environment, Ireland in the early 1930s, or even more specifically, during the Eucharistic Congress of 1932, what else is a documentary film going to reflect but a constructed society in all the glory of its construction rather than some transcendent 'reality' to which the film camera had access simply because it records the profilmic environment.

So much of people's understanding of documentary film remains framed by a rather astonishingly naive belief in its qualities of objectivity and neutrality that it is still thought of as a medium of record and recording rather than one of discourse. Even in the age of Michael Moore, people identify the person, not the medium, as the locus of the problem, if there is one. If you don't agree with Michael Moore's politics, then his films must be tainted by his editorial point of view and therefore not real documentaries. If it is as easy as this, then the corollary must also be true: that a film is only a real documentary if you agree with its interpretation of the world. Think about that for a minute, and you begin to see the depths of the problem. You also begin to realise the significance of what we might term 'public culture' to the debate. Ontological, epistemological, and social consensus are instrumental in any concept of 'public culture' and these are also the things that define the ethical and aesthetic boundaries of forms of representation that engage with public culture, like documentary films.

The fact is that the persistent belief in documentary as a medium is actually an acknowledgment of an ethical and epistemological contract between the viewer and the filmmaker that the filmmaker is trying to tell as much of the truth as they are capable of from their point of view and that the audience is going to accept this and believe that what they see in these films is a reasonable proxy for consensus reality. Now even that sentence is so convoluted and qualified, it shows you both how tenuous the relationship between 'truth' and documentary really is, and also how crucial the involvement of the viewer is, both as the individual person and as a viewing public.

It's such a complicated and qualified set of terms that when I say that $E u$ charistic Congress 1932 is a filmed record of an event, the simplest way to then think of it is as something innocent, incidental, and lacking ideology an eyewitness account. The truth is that even by the act of filming, and then by the act of presenting that film to the public in any forum, Fr. Browne was presenting an argument about the way he thought the world was, could and should be seen. Now that that moment in time has passed into history, the film takes on even greater significance, because, stripped of its sense of newness and lacking an explicit rhetorical or authorial structure, it appears even more 
'innocent', more 'historical', more unquestionable as a 'mere' record of an important event. People don't say that about Triumph of the Will, but, on one level, it is just that - a filmed record of a major public event which occurred around the same point in time, 1934, just two years after the Eucharistic Congress. To the end of her life Leni Riefenstahl continued to argue that that's all the film ever was - she simply filmed what she saw and presented it as well as she could. No one lets her get away with that. Why should any filmmaker anywhere ever be let away with that? Documentary film is an inherently political act. Contributing to the historical record is an inherently ideological act. Public Culture, which is, in its very nature, something defined through public discourse, and acts of representation and record contribute to such discourse in significant ways.

\section{Congress}

Writing in 1982 Joseph Lee and Gearoid O'Tauthaigh said that the Eucharistic Congress of 1932 'witnessed a spontaneous popular enthusiasm for the Catholic Church in Ireland,' (Lee and O'Tuathaigh 1982: 192). The word 'spontaneous' is interesting given how evidently and extensively mediated and negotiated the event itself was, from high profile publicity stunts like the building of a round tower in front of Trinity College and an altar on O'Connell Bridge, the garden party thrown in the grounds of Blackrock College by Dr. John Charles McQuaid, or the erection of a Crucifix in the Dail Chamber, to public spectacles like the Mass in Phoenix Park attended by more than a million people where the army formed an honour guard for the celebrants or the seemingly endless parades throughout the country, few of which were actually religious parades per se - they consisted mainly of cheering crowds waving papal flags as the Papal delegates drove past. Moira Sweeny's 2002 documentary "The Best Catholics...", (shown as part of RTÉ's Leargas series), was a little more layered in outlining the organisation of and execution of the Eucharistic Congress. Again, the parallel with the mass spectacle at Nuremberg is not inappropriate, even if the ideology is different. Public cultures differ, but the mechanisms by which they are constructed are consistent, and here in the 1930s with the world in Grierson's 'drastic phase of change', there was a lot of construction going on. Even the title of Sweeney's film gives us the basic point being made; which is that the hosting of the Eucharistic Congress in Free State Ireland was a statement on a Global scale of the commitment of the Irish Free State to Catholicism.

Even deeper than that and more local in focus, as Patrick Murray points out in his book Oracles of God (2000) and as the Sweeney film re-iterates, it 
was a specific, directed, political statement by the newly elected Fianna Fail government under Eamon deValera of the adherence of his party to the Catholic line. You have to remember that in the election campaign of 1932, Fianna Fail's hardline republican background was being presented as a threat to public order and the authority of the Catholic Church. Murray makes this point, examining the electoral propaganda circulated by Cumman na nGaedheal, which linked deValera's party with communism and secularism, a deadly twin threat to the Church in Ireland if ever there was one. As he points out, the Eucharistic Congress

... represented one of the most considerable and enduring publicity triumphs of deValera's career. His ceremonial appearances in the company of Irish bishops and senior churchmen from all over the world in the presence of hundreds of thousands of people marked the symbolic end to the loss of official Church approval from which he and his associates had suffered so badly since 1922, both politically and personally, and his emergence as a Catholic statesman of unexampled orthodoxy. (Murray, 2000: 262).

Few would now dispute this, or disagree that regardless of the level of faith or belief on the part of individual people attending Mass in the Phoenix Park, the public events around the Congress were organised to boost morale and provide the papal delegation and the world with images of the Irish people waving papal flags in their millions. This may be public culture, or the public display of cultural affiliation, or even the orchestration of the public display of an officially promulgated cultural affiliation - whatever it is, it is public, and it was recorded.

Again, I have to refer you to The Real Ireland for details on the comparative underdevelopment of documentary film in Ireland throughout the early twentieth century. To summarise quickly though, official governmental sponsorship of filmmaking was essentially nonexistent until well into the 1940s, meaning that the gap was filled by amateur filmmakers of varying levels of expertise and with relatively limited distribution or 'public' exposure, and occasional foreign filmmakers who arrived with big budgets and received tacit or explicit governmental approval to operate, and, frequently, endorsement of the finished product.

Most of the films made around the Eucharistic Congress were amateur filmed records of parades or other events in local communities. The catalogue of the Irish Film Archive at the Irish Film Institute lists five examples of this. There is a film in the William Crawford collection, scenes taken in Dublin with intertitles identifying the papal delegates. There is another by Richard Johnson, also of Dublin scenes, seemingly even more incidental than the Crawford footage, including, as the catalogue says 'footage of the 1932 Eucharistic Con- 
gress processing through Dublin city and of family activities in a garden and on a sea shore' (IFI). There are scenes in the George collection, shot by JCG George, again of various Dublin events. And then there are scenes by Thomas J. Breen of Tipperary, which are interesting in that they feature footage of Congress events outside of Dublin. All of these films are amateur shorts, essentially home movies. Does this exclude them from consideration as documentary films? No. Yes in terms of Griersonian social documentary, maybe, but amateur films of this nature contribute to what Sharon R. Sherman writes of in terms of a folkloric practice of filmmaking whereby a culture that documents itself in this way is also involved in a process of self-inscription, contributing to an accumulation of lore. For Grierson, such films would tend more towards the pre-documentary forms of non-fiction film that his movement had supplanted through professionalism and a commitment to social partnership that a folkloric tradition basically predates. The Eucharistic Congress was a significant event, it was certainly set up to be so, and therefore, we see here the ripple effect on public culture - people turn up at the event, film the event for themselves and so further inflate the significance of what they saw both on a personal level and now, as we look back at the footage years later, on an historical level,

Fr. Browne's Eucharistic Congress 1932 is related to these films in that it is an amateur endeavour and it is comprised entirely of scene after scene recording what went on. But it is a much bigger undertaking in every sense - a much longer film and one made by a filmmaker who wasn't exactly an amateur even if he wasn't being paid to do it. Just to give you a brief bit of background on Fr. Browne, he was a Jesuit priest whose lifelong love of photography produced many thousands of striking images of twentieth century Ireland, many of them collected in a series of photographic volumes edited by fellow Jesuit Fr. Eddie O'Donnell. There is more detail on Fr. Browne in both in each of the volumes and in Eddie O'Donnell's Fr. Browne: A Life in Pictures from 1997. What is important is that though Fr. Browne was not a professional filmmaker per se, he was a successful photographer whose aesthetic sensibility is evident in the few films he did, in fact, make in the course of his life. Eucharistic Congress 1932 is the second that we know of, the first being a docu-drama called Castle Rising made in 1931.

Fr. Browne represents the second most high profile in a line of filmmaking priests and other religious to emerge out of Ireland in the twentieth century. This is something really rather special in documentary terms, something I have seen relatively little written about in the histories of documentary film in other countries. In the 2004 book Keeping it Real, which I co-edited with Ruth 
Barton, we featured an article by Sunniva O'Flynn, then curator of the Irish Film Archive, on this topic, in which she remarks that the phenomenon may be unique to Ireland at least in terms of its prevalence (2004: 39). In 2009, Harvey O'Brien co-ordinated a major research project on Radharc, a professional independent filmmaking company run by Catholic Priests which operated successfully for nearly forty years on Irish television, producing some 400 films in 75 different countries. I mention Radharc now because Fr. Joe Dunn, co-founder of Radharc and director of many of its films, is a perfect illustration of the point I'm trying to make. Fr. Dunn never was a parish priest, but wrote in his recollections No Tigers in Africa! (1986) that he, like any other priest, said mass every morning and made visits to his congregation, noting that his congregation was, in essence, the viewing audience on RTE. He compared the advent of television to that of the printing press, and noted the potential parallel between the spread of the Protestant Reformation and the printing press and what could be achieved with television. He wrote: "If it can be accepted now that significant media change such as the advent of printing, and now radio and television, can bring about substantial changes in society, then an institution like the Catholic Church, which is essentially an institution for communicating a message, should stay close to the action, and make every effort to understand what's happening." (Dunn, 1986: 125).

What Dunn is suggesting here is that the mission of the Church and the mission of the media practitioner are not a million miles apart, and that the fusion of the two is practically the duty of the former as well as, in his case, the latter. This chimes in very neatly with the idea of social documentary in general terms, and although we could argue that Fr. Browne had no such ambitions in making Eucharistic Congress 1932, which is an 'innocent' 'record' of a public event, that would be giving very little credit to him as a Priest and an artist. Browne's film is a beautifully photographed series of scenes of action which, in itself, is as ideologically loaded as action can be. No more or less so than the political rally at Nuremberg was the religious rally in Dublin and throughout Ireland organised as a conscious demonstration of the power and reach of the Catholic Church in Ireland, and this was intended as a message of joy as well as triumph. In filming the event, Fr. Browne was absolutely contributing to the promulgation of Catholic Public Culture - both providing a record of what transpired and spreading a message that it had. As much as Fr. Joe Dunn, the camera, both stills and movie, for Fr. Browne was a means of spreading a sensibility informed by Catholic teaching and religious belief. The images may not have always been loaded, but the person creating them was deeply informed by his faith and a sense of its mission. Browne's scenes 
of Papal banners flying over Dublin, of the million people attending Mass in the Phoenix park where an elaborate Altar had been erecred for the occasion, of Irish clergy mixing with senior figures from the Catholic Hierarchy, of the Irish Army forming an honour guard for the Papal Nuncio, and of the aforementioned landmarks and decorations built specifically for the Congress were 'incidental' records of deliberately icongraphical materials. Browne's romantic humanism was deeply grounded in his faith, and so by definition, everything his eye, and his camera-eye, saw was imbued with the dignity and grace of the divine.

If you still cling to the idea that this is an innocent eyewitness film, consider Alan Rosenthal's observation about the idea of 'bearing witness' which we associate with documentary as record. He says:

I now see the concerned film maker not only as one who tries to bring about direct change, but as one who bears witness. This 'bearing of witness' has two elements. On a modest level it means that the film maker is interested in telling us about a certain truth. It is not 'the truth' or 'the eternal message' but is rather a very personal statement that says 'This film arises out of my feelings, background, and integrity, and on the basis of what I show and how I show it you can take it or leave it for what it's worth'... On a different level of bearing witness the film maker is one who says: 'This is our world. See its joy and be happy. But see its sorrow and learn from it, and don't say no one ever told you what the world was like.' This kind of bearing witness is not something one does logically. It is something one does compulsively. (Rosenthal,1980: 31).

I think no reference to a film made by a priest can take the phrase 'bearing witness' as a given, and I wouldn't presume to do so here. As Rosenthal observes, the process of 'bearing witness' is also a process of giving testament, and I can think of no better description of what Fr. Browne's Eucharistic Congress 1932 says as a documentary film simply by 'bearing witness' than Rosenthal's second element - 'This is our world. See its joy and be happy.' The film does not have to have a voice over or the structure of a rhetorical documentary to make this argument, and I think it is evident when we consider the context of how the event came about, the role of the Church, and the particular background of the man who made this film, that it is far from incidental, accidental or 'innocent' in contributing to the shape and sensibility of Catholic Public Culture.

\section{Bibliographic references}

Aitken, I. (ed.). (1998). The documentary film movement: an anthology. Edinburgh University Press. 
Aitken, I. (2013). John Grierson and the documentary film movement. In B. Winston (ed.), The documentary film book (pp. 129-137). BFI.

Barton, R. \& O'Brien, H. (eds.) (2004). The real Ireland: irish film and television. Wallflower Press.

Dunn, J. (1986). No tigers in Africa! Recollections and reflections on 25 years of Radharc. Columba Press.

Inglis, T. (1998). Moral monopoly: the rise and fall of the catholic church in modern Ireland. UCD Press.

Kiberd, D. (1995). Inventing Ireland: the literature of a modern nation. Jonathan Cape.

Lee, J. \& O'Tuathaigh, G. (1982). The age of DeValera. Irish Book Centre.

Murray, P. (2002). Oracles of God: the roman catholic church and irish politics 1922-37. UCD Press.

Nichols, B. (2010). Introduction to documentary, $2^{\text {nd }}$ ed.. Indiana University Press.

O'Brien, H. (2004). The real Ireland: the evolution of Ireland in documentary film. Manchester University Press.

Rosenthal, A. (1980). The documentary conscience: a casebook in filmmaking. University of California Press.

Winston, B. (ed.) (2013). The documentary film book. BFI. 